\title{
Article \\ Time Limit of Gold Mineralization in Muping-Rushan Belt, Eastern Jiaodong Peninsula, China: Evidence from Muscovite Ar-Ar Dating
}

\author{
Binghan Chen ${ }^{1,2, *}$, Jun Deng ${ }^{2}$ and Xingzhong Ji ${ }^{1}$ \\ 1 MNR Key Laboratory of Metallogeny and Mineral Assessment, Institute of Mineral Resources, CAGS, \\ Beijing 100037, China; jxz_cugb@126.com \\ 2 State Key Laboratory of Geological Processes and Mineral Resources, China University of Geosciences, \\ Beijing 100083, China; djun@cugb.edu.cn \\ * Correspondence: chenbinghan@cags.ac.cn; Tel.: +86-10-68999511
}

Citation: Chen, B.; Deng, J.; Ji, X. Time Limit of Gold Mineralization in Muping-Rushan Belt, Eastern Jiaodong Peninsula, China: Evidence from Muscovite Ar-Ar Dating. Minerals 2022, 12, 278. https:// doi.org/10.3390/min12030278

Academic Editors: Kunfeng Qiu and Aleksei V. Travin

Received: 7 December 2021 Accepted: 17 February 2022 Published: 23 February 2022

Publisher's Note: MDPI stays neutral with regard to jurisdictional claims in published maps and institutional affiliations.

Copyright: (C) 2022 by the authors. Licensee MDPI, Basel, Switzerland. This article is an open access article distributed under the terms and conditions of the Creative Commons Attribution (CC BY) license (https:// creativecommons.org/licenses/by/ $4.0 /)$.

\begin{abstract}
Controversy surrounds the genetic relationship between gold mineralization and magmatism, especially in deposits in granite. Jiaodong Peninsula is the leading gold province in China, and most deposits are in Mesozoic granites; moreover, debate on the genesis persists. In eastern Jiaodong, the Muping-Rushan gold belt produces mainly quartz-sulfide vein-type gold, and the Upper Jurassic Kunyushan granite and Late Lower Cretaceous Sanfoshan granite are the wall rock. Precise mineralization ages should be identified to determine whether gold is related to the intrusion. In this study, three gold deposits (Sanjia, Yinggezhuang, and Xipo) from two ore-controlling faults were considered. Muscovites from quartz-sulfide veins and beresite were selected for Argon-Argon dating. The results obtained were $116.51 \pm 0.47 \mathrm{Ma}, 120.02 \pm 0.38 \mathrm{Ma}$, and $121.65 \pm 0.48 \mathrm{Ma}$ for the three deposits, respectively. The mineralization lasted about $5 \mathrm{Ma}$ in the Muping-Rushan gold belt. The test results showed that the mineralization was 16 Ma later than the intrusion time of Kunyushan granite and was earlier than that of Sanfoshan granite. Only the cooling age overlapped with the mineralization age. Previous studies have demonstrated that the ore fluid is of medium-low salinity and medium-low temperature. No typical high-low temperature mineral assemblage exists in the Muping-Rushan gold belt. Hence, gold deposits in Muping-Rushan gold belt could not be categorized as intrusion-related gold type.
\end{abstract}

Keywords: muscovite; Ar-Ar dating; magmatism; mineralization

\section{Introduction}

Jiaodong peninsula is a well-known gold province with $5000 \mathrm{t}$ of proven gold resources in China [1-3]. Most gold deposits are located in the Late Jurassic granite, and several studies have categorized these deposits into the magmatic-hydrothermal and intrusionrelated gold deposits [4]. In terms of structural control and quartz-pyrite-muscovitecarbonate alteration assemblages, gold deposits in Jiaodong share similar features with orogenic gold deposits [5,6]. Anorogenic and decratonic gold deposit models [7,8] have been proposed based on tectonic setting. The Jiaodong type gold deposit is also used to cover the features $[9,10]$. The Muping-Rushan gold belt lies in Eastern Jiaodong and mainly produces the quartz-sulfide vein type ore [11]. Previous studies have used isotope tracing or microthermometry to categorize the gold deposit as magmatic-hydrothermal [12-22].

The time limit of mineralization and magmatism can be determined to solve the problem of genesis. Many geochronology studies have been conducted in the Jiaodong Peninsula, using different methods on altered or accessory minerals, and varying results have been reported, but they mainly tend to $120 \mathrm{Ma}[1,23]$. Geochronology studies in the Muping-Rushan gold belt have reported a wide range of results [15,24-30]; however, the dating method and samples used must be considered to determine the relationship between 
mineralization and magmatism. More geochronological studies on the gold deposits are required to clarify the genesis of gold deposits in the Muping-Rushan gold belt.

Recent studies have investigated multiple dating methods and minerals to determine mineralization time [31,32]. Muscovite is an ideal alteration mineral and is likely related to mineralization. Muscovite is not easily affected by hydrothermal activity after mineralization, and the closure temperature of muscovite in Ar-Ar dating is around the mineralization temperature $\left(\sim 350{ }^{\circ} \mathrm{C} \pm 50{ }^{\circ} \mathrm{C}\right)$ [1]. As the influence of thermal disturbance on ${ }^{40} \mathrm{Ar}-{ }^{39} \mathrm{Ar}$ dating can be ignored, the ${ }^{40} \mathrm{Ar}-{ }^{39} \mathrm{Ar}$ ages of muscovite can accurately show the time limit of gold mineralization.

In this study, muscovites from three gold deposits in the Muping-Rushan gold belt were selected for the Argon-Argon (Ar-Ar) dating to determine the mineralization age. Next, the mineralization age was compared with the duration of magmatic activity to determine the relationship between magmatism and mineralization. This work is expected to fill the gap in the study of mineralization dating in the Muping-Rushan gold belt and provide a deeper understanding of the metallogenic background in the Eastern Jiaodong Peninsula.

\section{Regional Geological Setting}

The Jiaodong Peninsula can be divided into the Jiaobei and Sulu Terranes by the Wulian-Qingdao-Yantai fault [33], as shown in Figure 1a. More than $4000 \mathrm{t}$ of proven reserves and 150 gold deposits have been discovered [34,35]. The NNE-trending and detachment faults determine the occurrence of gold deposits [10,35]. Mesozoic granites host most of the gold deposits, and only a minor amount is located in the Archean metamorphic rocks $[10,35]$. Continental collision and subduction of the oceanic lithosphere occurred in Jiaodong, Yangtze Craton, and the Pacific Plate subducted below the North China Craton during the Triassic and Jurassic, respectively [24,36-38].

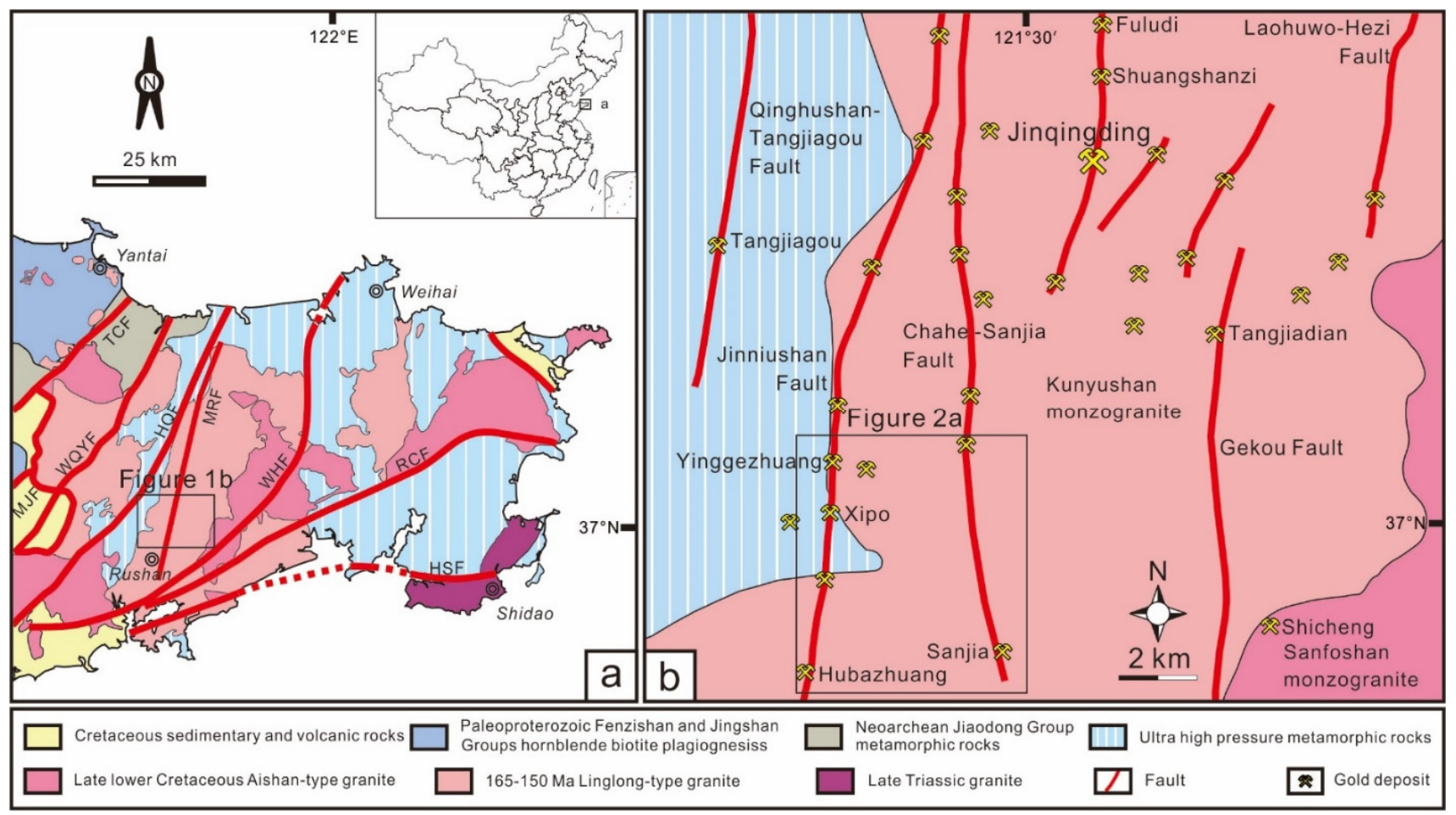

Figure 1. Regional geological map of the Eastern Jiaodong Peninsula (a) and the Muping-Rushan gold belt (b) (modified from [1,34]). HQF-Haiyang-Qingdao fault; HSF-Haiyang-Shidao fault; MRF-Muping-Rushan fault; RCF-Rongcheng fault; TCF-Taocun fault; WHF-Weihai fault; WQYFWulian-Qingdao-Yantai fault. 
The Archean tonalite-trondjemite-granodiorite (TTG, 2.9-2.5 Ga) gneisses are the regional basement [39], which is overlaid by the Neoarchean Jiaodong Group and the Proterozoic Fenzishan, Jingshan, and Penglai Groups. The Jiaodong Group is composed of meta-igneous and metasedimentary rocks $[40,41]$; the Fenzishan and Jingshan Groups are made up of calc-silicates, schist, amphibolite, and marble [42-44]. The Neoproterozoic Penglai Group is composed of slate, quartzite, and marble [45].

In the Mesozoic, magmatic activity is categorized into the Late Triassic, Late Jurassic (165-150 Ma), Early Cretaceous (132-123 Ma), and Late Early Cretaceous [35,46,47]. Only the Late Jurassic and Late Early Cretaceous intrusions are found within the gold belt [1].

The Late Jurassic Kunyushan granite derived from the partially molten Neoarchean lower crust $[48,49]$ is the main wallrock in the gold belt, as shown in Figure 1b. Kunyushan granite can be sub-divided into Duogushan, Wuzhuashan, and Washan granites, which have sensitive high resolution ion microprobe (SHRIMP) zircon ages of $161 \pm 1 \mathrm{Ma}$, $160 \pm 3 \mathrm{Ma}$, and 138-146 Ma [50] as well as ${ }^{40} \mathrm{Ar} /{ }^{39} \mathrm{Ar}$ biotite cooling ages of 135-147 Ma, 120-123 Ma, and 126-131 Ma, respectively (Table 1) [29]. The Duogushan granite is a medium grained weak gneissic granidiorite containing epidote. The lithology of Washan granite is medium grained weak gneissic monzogranite. The Wuzhuashan granite is a fine-medium grained weak gneissic monzogranite. No sharp boundary exists between the Wuzhuashan and Washan monzogranite.

Table 1. Age of the wallrock in the Muping-Rushan gold belt.

\begin{tabular}{|c|c|c|c|c|c|}
\hline Intrusion time & Granite & Mineral & Method & Age (Ma) & References \\
\hline \multirow{6}{*}{ Late Jurassic (Kunyushan) } & \multirow{2}{*}{ Duogushan } & Zircon & SHRIMP & $161 \pm 1$ & {$[50]$} \\
\hline & & Biotite & ${ }^{40} \mathrm{Ar} /{ }^{39} \mathrm{Ar}$ & $147-135$ & [29] \\
\hline & \multirow{2}{*}{ Washan } & Zircon & SHRIMP & $146-138$ & {$[50]$} \\
\hline & & Biotite & ${ }^{40} \mathrm{Ar} /{ }^{39} \mathrm{Ar}$ & $131-126$ & [29] \\
\hline & \multirow{2}{*}{ Wuzhuashan } & Zircon & SHRIMP & $160 \pm 3$ & [51] \\
\hline & & Biotite & ${ }^{40} \mathrm{Ar} /{ }^{39} \mathrm{Ar}$ & $123-120$ & [29] \\
\hline \multirow{6}{*}{ Late Early Cretaceous } & Liudusi & Zircon & LA-ICP-MS & $113 \pm 2$ & [51] \\
\hline & \multirow{4}{*}{ Sanfoshan } & \multirow{4}{*}{ Zircon } & \multirow{2}{*}{ SHRIMP } & $114 \pm 1$ & [51] \\
\hline & & & & $111 \pm 3$ & [51] \\
\hline & & & \multirow{2}{*}{ LA-ICP-MS } & $113 \pm 1$ & [50] \\
\hline & & & & $118 \pm 1$ & {$[52]$} \\
\hline & Xiamashan & Zircon & LA-ICP-MS & $111 \pm 2$ & {$[51]$} \\
\hline
\end{tabular}

The Late Early Cretaceous Aishan monzogranite intrusions derived from mixed crustmantle and partly depleted mantle [50] are shown in Figure 1b. Within the gold belt, the Aishan intrusion can be sub-divided into the Sanfoshan, Liudusi, and Xiamashan granites, which have laser ablation inductively coupled plasma mass spectrometry (LA-ICP-MS) zircon ages of $113 \pm 1 \mathrm{Ma}-118 \pm 1 \mathrm{Ma}, 113 \pm 2 \mathrm{Ma}$, and $111 \pm 2 \mathrm{Ma}$, respectively [50-52] The Sanfoshan granite has a SHRIMP zircon age of $111 \pm 3 \mathrm{Ma}-114 \pm 1 \mathrm{Ma}$ [51]. Only a few gold deposits are within the Sanfoshan monzogranite.

Lamprophyre dikes in the Sulu region provided zircon $\mathrm{U}-\mathrm{Pb}$ ages of $118.5 \pm 2.9 \mathrm{Ma}$ and $119.3 \pm 0.8 \mathrm{Ma}$ [53]. Zhu et al. [54] reported that the zircon U-Pb ages of lamprophyre in Denggezhuang were mainly $120 \pm 2 \mathrm{Ma}$ and $153 \pm 2 \mathrm{Ma}$. The age of lamprophyres in the Jiaodong Peninsula lasted from pre- to post-mineralization [53].

Four main ore-controlling faults, namely, the Hezi-Gekou, Jiangjunshi-Quhezhuang, Jinniushan, and Qinghushan-Tangjiagou faults, control over 20 gold deposits, as shown in Figure 1b. Muscovite samples from the fault gouge in the Denggezhuang and Jinqingding gold deposits were chosen for the Ar-Ar chronology study; the results show that the brittle 
deformation age of the Muping-Rushan shear zone is $119.6 \pm 1.2 \mathrm{Ma}-115.8 \pm 1.4 \mathrm{Ma}$ [55]. Sulfide-quartz vein and beresite are the main ore types.

\section{Ore Deposit Geology}

The Sanjia gold deposit $\left(121^{\circ} 36^{\prime} 13^{\prime \prime}-121^{\circ} 37^{\prime} 28^{\prime \prime} \mathrm{E}, 36^{\circ} 56^{\prime} 31^{\prime \prime}-37^{\circ} 00^{\prime} 1^{\prime \prime} \mathrm{N}\right)$ is located approximately $12 \mathrm{~km}$ northeast of Rushan City with an area of $9.95 \mathrm{~km}^{2}$. The main orecontrolling fault is Chahe-Sanjia (Figure 2). The main orebody is No. I-1, which occurs between $+180 \mathrm{~m}$ and $-840 \mathrm{~m}$, strikes NNW, and is up to $520 \mathrm{~m}$ long along the strike and up to $1040 \mathrm{~m}$ long along the dip. The thickness of orebody No. I-1 is $0.3-5.83 \mathrm{~m}$ with an average of $1.73 \mathrm{~m}$. The grade is typically $2.00-16.00 \mathrm{~g} / \mathrm{t}$ with an average of $5.07 \mathrm{~g} / \mathrm{t}$. The ore types are quartz pyrite vein and beresite.

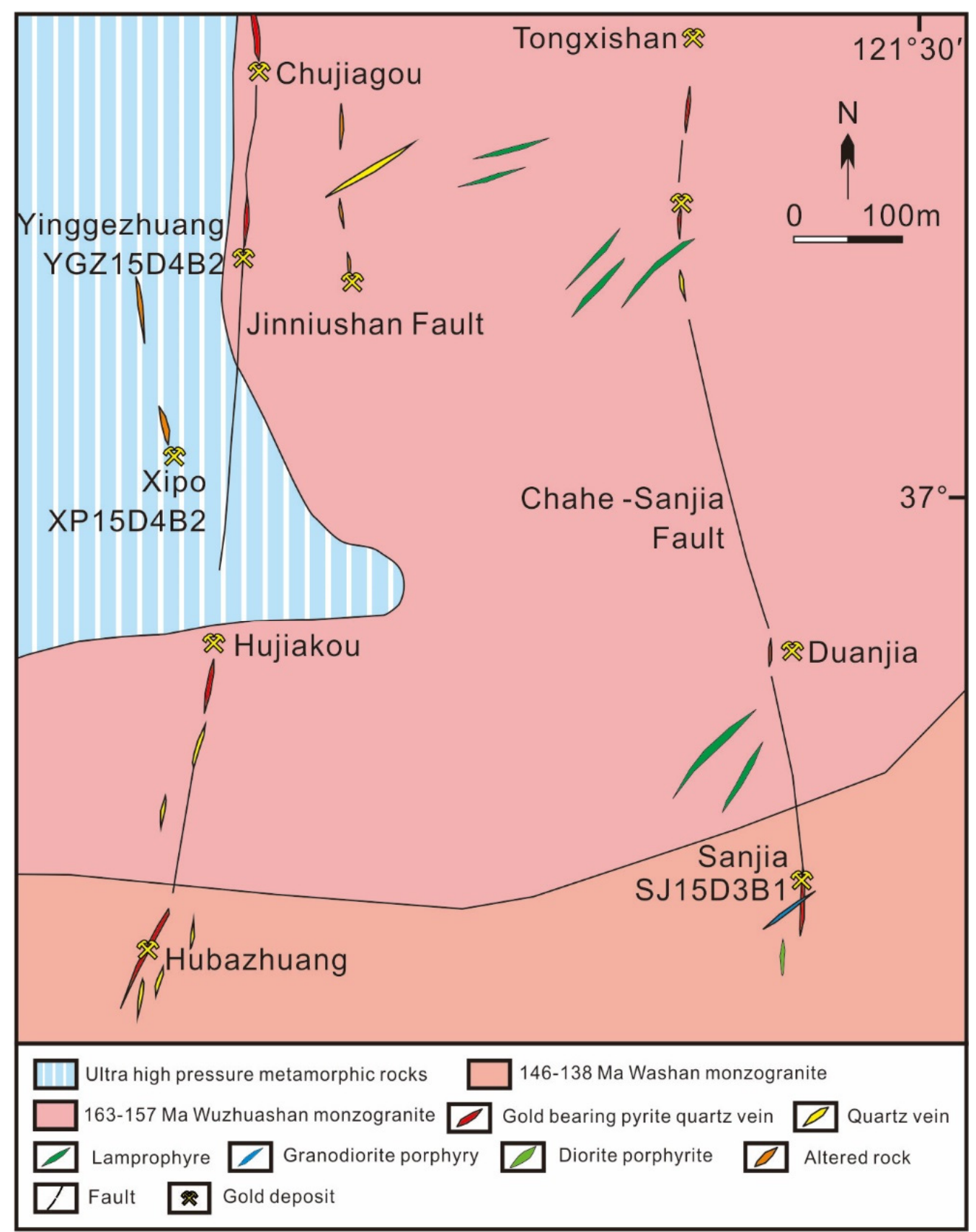

Figure 2. Geological map of the study area in the Muping-Rushan gold belt (adapted from [11]). 
The Yinggezhuang gold deposit $\left(121^{\circ} 33^{\prime} 43^{\prime \prime}-121^{\circ} 34^{\prime} 13^{\prime \prime} \mathrm{E}, 37^{\circ} 2^{\prime} 19^{\prime \prime}-37^{\circ} 3^{\prime} 6^{\prime \prime} \mathrm{N}\right)$ is located $14 \mathrm{~km}$ northeast of Rushan City with an area of $0.85 \mathrm{~km}^{2}$ and a proven reserve of $9 \mathrm{t}$. The Jinniushan fault is the ore-controlling fault (Figure 2), and its general trend is North-South dipping to the East with a dip angle of $51^{\circ}-88^{\circ}$. The orebodies occur at depths between $+163 \mathrm{~m}$ and $-410 \mathrm{~m}$, strike north-south, and are up to $50-450 \mathrm{~m}$ long along the strike and up to $520 \mathrm{~m}$ long along the dip. The grade is typically 1.54 to $19.00 \mathrm{~g} / \mathrm{t}$. The ore is mainly the quartz sulfide vein and beresite types. Amphibolite and gneiss occur as xenoliths in the mining area. Dikes are also present. A sample was collected from orebody No. IV.

The Xipo gold deposit $\left(121^{\circ} 33^{\prime} 50^{\prime \prime}-121^{\circ} 34^{\prime} 20^{\prime \prime} \mathrm{E}, 37^{\circ} 0^{\prime} 44^{\prime \prime}-37^{\circ} 1^{\prime} 15^{\prime \prime} \mathrm{N}\right)$ is a small gold deposit south of the Yinggezhuang gold deposit. The Jinniushan fault controls the occurrence of the orebodies (Figure 2). The orebodies strike almost north-south, are approximately $700 \mathrm{~m}$ long along the strike and up to $280 \mathrm{~m}$ long along the dip, and dip to eastward with a dip angle of $53^{\circ}-61^{\circ}$. In the north, the $10 \mathrm{~m}$ wide orebody No. I-1 was selected for sample collection.

In the Muping-Rushan gold belt, potassium alteration, silicification, sulfidation, and sericitization are the main alteration types; quartz and pyrite are the main gold-bearing minerals; muscovite is the most common alteration mineral. Other sulfides, such as chalcopyrite and galena, are also common gold-bearing minerals. The paragenesis is shown in Figure 3 [11].

\begin{tabular}{|c|c|c|c|}
\hline Mineral & Pre & Main & Post \\
\hline Pyrite & & & \\
\hline Quartz & & & \\
\hline Muscovite & & & \\
\hline Gold & & & \\
\hline Sulfide & & & \\
\hline
\end{tabular}

Figure 3. Mineral paragenesis (adapted from [11]). The intensity and scale of mineral occurrence are indicated by the thickness of the line.

\section{Sampling and Analytical Methods}

In this study, samples from the Sanjia, Xipo, and Yinggezhuang gold deposits were selected for dating (Figure 2). The gold deposits are located on the Jinniushan and ChaheSanjia faults, which can improve and validate the dating result in this gold belt.

The beresite sample collected for the Ar-Ar test in the Sanjia gold deposit was from a depth of $-226 \mathrm{~m}$, as illustrated in Figure 4a,b. The hand sample was grayish green and medium-coarse grained with an unequal grain texture and a massive structure as shown in Figure $4 \mathrm{~b}$. The main minerals were muscovite, quartz, and pyrite. In the hand sample, the quartz ( $30 \%$ content) was grayish white, medium-coarse grained, and of a greasy luster. The muscovite ( $50 \%$ content) appeared grayish green, and the pyrite ( $15 \%$ content) was sparsely distributed.

The quartz sulfide vein collected for the Ar-Ar test in the Xipo gold deposit was from a depth of $+35 \mathrm{~m}$ as shown in Figure $4 \mathrm{~d}$,e. The hand sample was grayish white, 
medium-fine grained, and had an unequal grain texture and veinlet structure as shown in Figure $4 \mathrm{e}$. The main minerals were quartz, muscovite, pyrite, and potassium feldspar. In the hand sample, the quartz (50\% content) was smoke gray and medium-coarse-grained. The muscovite (30\% content) was grayish-green and fine-grained, and the pyrite (15\% content) was light copper with a net vein output; the potassium feldspar ( $5 \%$ content) was flesh red, plate-shaped, and of a greasy luster.

The quartz-sulfide vein collected for the Ar-Ar test in the Yinggezhuang gold deposit was from a depth of $-335 \mathrm{~m}$ in orebody the No. IV as shown in Figure $4 \mathrm{~g}$,h. The surrounding rock was altered with potassic feldspar, and the occurrences of the upper and lower walls of the orebody were $65^{\circ} \angle 64^{\circ}$ and $80^{\circ} \angle 72^{\circ}$, respectively. The hand sample appeared smoke gray and had a medium-fine grained texture and vein structure; the main minerals were quartz, muscovite, and pyrite as shown in Figure $4 \mathrm{~h}$. In the hand sample, quartz (55\% content) was smoke gray and medium-coarse grained. The muscovite ( $25 \%$ content) was light green or dark green. The pyrite ( $15 \%$ content) was categorized into two types based on particle size: the coarse particles were mostly distributed, whereas the fine particles mostly had vein shapes.
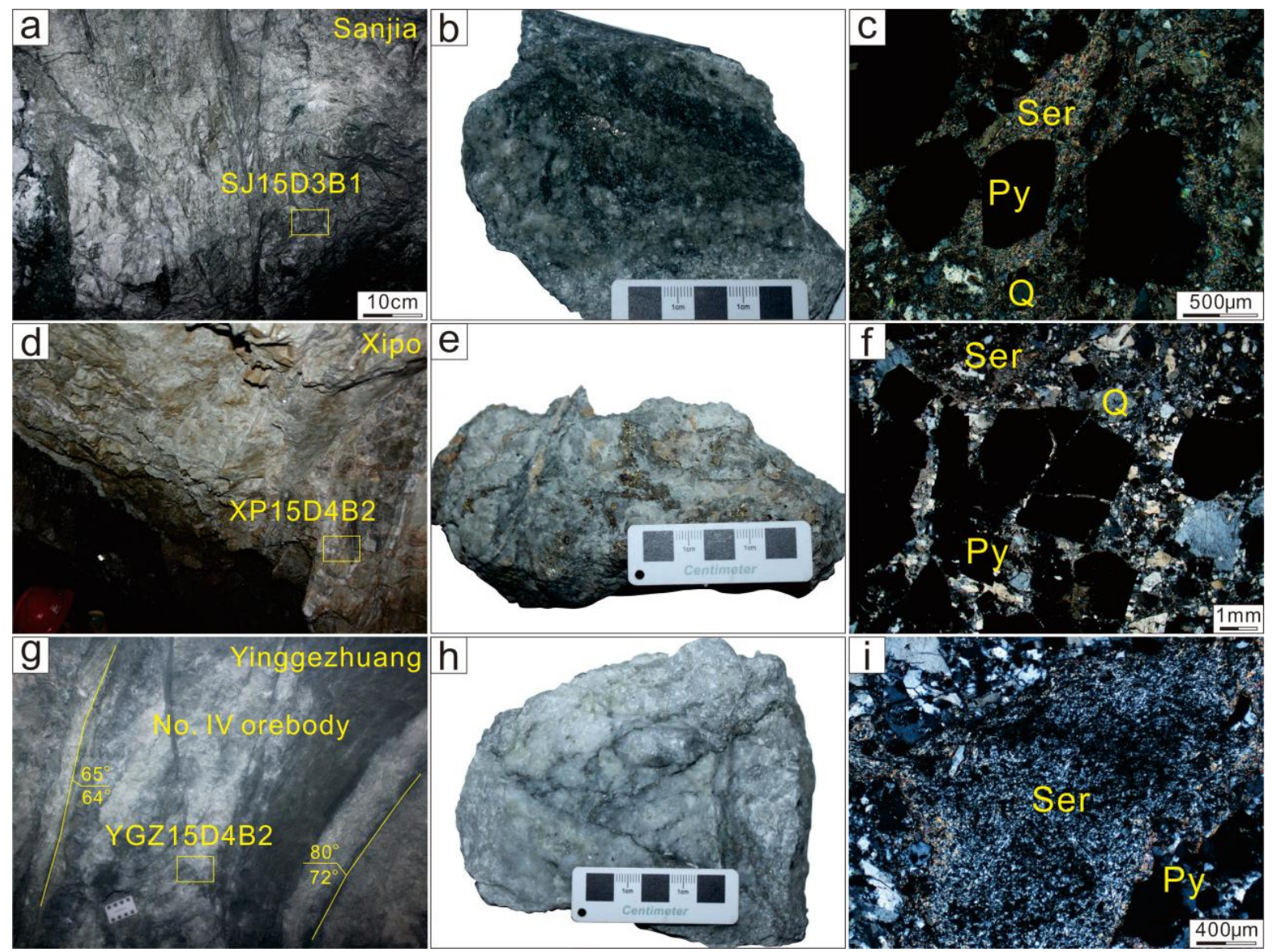

Figure 4. Sampling location and microscopic image showing the relationship between muscovite and mineralization in the Sanjia, Xipo, and Yinggezhuang gold deposits: (a) sampling location of the beresite in the Sanjia gold deposit, (b) hand sample of beresite, (c) muscovite coexists with pyrite, (d) sampling location of the quartz-sulfide vein in the Xipo gold deposit, (e) hand sample of quartz-sulfide vein, (f) muscovite coexists with pyrite, (g) sampling location of the quartz-sulfide vein in the Yinggezhuang gold deposit, (h) hand sample of quartz-sulfide vein, (i) muscovite coexists with pyrite. Py—-pyrite; Ser-muscovite; $\mathrm{Q}$ - quartz. The yellow square shows the sampling location.

The pyrite, quartz, and muscovite coexist, and muscovite had a fine-grained structure, as shown in Figure 4c,f,i when viewed under a microscope. The selected muscovite was 
light green and occurred in a small aggregate, and the small muscovite aggregate did not contain any obvious crushing and deformation.

Before the experiment, the muscovite particles were sorted at Geoscience Exploration Technology Service Co., Ltd., Langfang, China. After screening and purification, the sorted muscovite was sent to Oregon State University, Corvallis, in the United States for the Ar-Ar test. The samples were sealed in a quartz bottle with the standard sample American Fish Canyon Tuff (28.201 $\pm 0.023 \mathrm{Ma}$; [56]) in separate vessels. Irradiation was performed in the CLICIT (Cd-Lined Inner-Core Irradiation Tube) for $75 \mathrm{~h}$.

For the ${ }^{40} \mathrm{Ar} /{ }^{39} \mathrm{Ar}$ experiment, the traditional furnace stage heating method (heating for $77 \mathrm{~s}$ and separation for $3 \mathrm{~min}$ ) was adopted. The experimental steps were obtained from [57,58]. The reported Ar isotope data were corrected using the system background, quality discrimination, radioactive decay, reactor-induced interference reaction, and atmospheric Ar. The decay constant was $5.530 \pm 0.048 \times 10^{-10} \alpha$ as reported in [59]. The isotope correction coefficient obtained using an ARGUS-VI-D mass spectrometer was $\left({ }^{36} \mathrm{Ar} /{ }^{37} \mathrm{Ar}\right)_{\mathrm{Ca}}=0.0002663 \pm 0.0000004,\left({ }^{39} \mathrm{Ar} /{ }^{37} \mathrm{Ar}\right)_{\mathrm{Ca}}=0.0006756 \pm 0.0000089$, $\left({ }^{40} \mathrm{Ar} /{ }^{39} \mathrm{Ar}\right)_{\mathrm{K}}=0.003823 \pm 0.000102$, and $\left({ }^{38} \mathrm{Ar} /{ }^{39} \mathrm{Ar}\right)_{\mathrm{K}}=0.012031 \pm 0.000019$. The atmospheric ${ }^{40} \mathrm{Ar} /{ }^{36} \mathrm{Ar}$ isotope ratio used for the age calculation was 295.50 . The plateau age was defined as having at least $30 \%$ of ${ }^{39} \mathrm{Ar}$ release cumulates, and at least three consecutive plateaus existed. The ${ }^{40} \mathrm{Ar} /{ }^{39} \mathrm{Ar}$ ratio of these plateaus should be consistent with their average value within the $95 \%$ confidence interval. Ar-Ar Calc was used to calculate and plot the plateau age [1].

\section{Ar-Ar Dating Results}

The experimental results are presented in terms of the plateau and inverse isochron ages as shown in Figure 5 and Tables S1-S3. The muscovite plateau age diagram of the Sanjia and Xipo gold deposits shows that Ar was slightly disturbed in the low-temperature heating stage but not significantly affected in the high-temperature stage as shown in Figure 5 a,c. The selected Ar release part was approximately $19.65 \%$ of the total gas age, and the plateau age was $116.51 \pm 0.47 \mathrm{Ma}, \mathrm{MSWD}=1.97$, and $\mathrm{P}=3 \%$. The amount of Ar released was small, and the total gas age was $114.31 \pm 0.44(2 \sigma), \mathrm{MSWD}=1.42$, and $\mathrm{P}=16 \%$. The inverse isochron age figure shows that the error in the data points was small. The inverse isochron age was $116.05 \pm 0.61 \mathrm{Ma}$, MSWD $=1.42$, and $\mathrm{P}=16 \%$, as shown in Figure $5 b$.

In the Xipo gold deposit, the selected Ar release part was approximately $33.59 \%$ of the total gas age, and the plateau age was $121.65 \pm 0.48 \mathrm{Ma}, \mathrm{MSWD}=2.05$, and $\mathrm{P}=1 \%$. The total gas age was $120.62 \pm 0.47 \mathrm{Ma}(2 \sigma)$. Because of the small amount of the Ar release part, the age might better reflect the age of the sample. In the inverse isochron age figure, the data point error was small. The inverse isochron age was $121 \pm 0.53 \mathrm{Ma}$, MSWD $=1.37$, and $\mathrm{P}=17 \%$, as shown in Figure $5 \mathrm{~d}$.

The muscovite plateau age of the Yinggezhuang gold deposit showed no obvious Ar loss or excess, and the selected samples were suitable for dating as shown in Figure 5e. The selected Ar release part was approximately $50.19 \%$; the plateau age was approximately $120.02 \pm 0.38 \mathrm{Ma}, \mathrm{MSWD}=3.45, \mathrm{P}=0 \%$, and the total gas age was $120.01 \pm 0.36(2 \sigma)$. In the inverse isochron age figure, the data point error was small. The inverse isochron age was $119.24 \pm 0.79 \mathrm{Ma}$, MSWD $=2.30$, and $\mathrm{P}=2 \%$, as shown in Figure $5 \mathrm{f}$. 

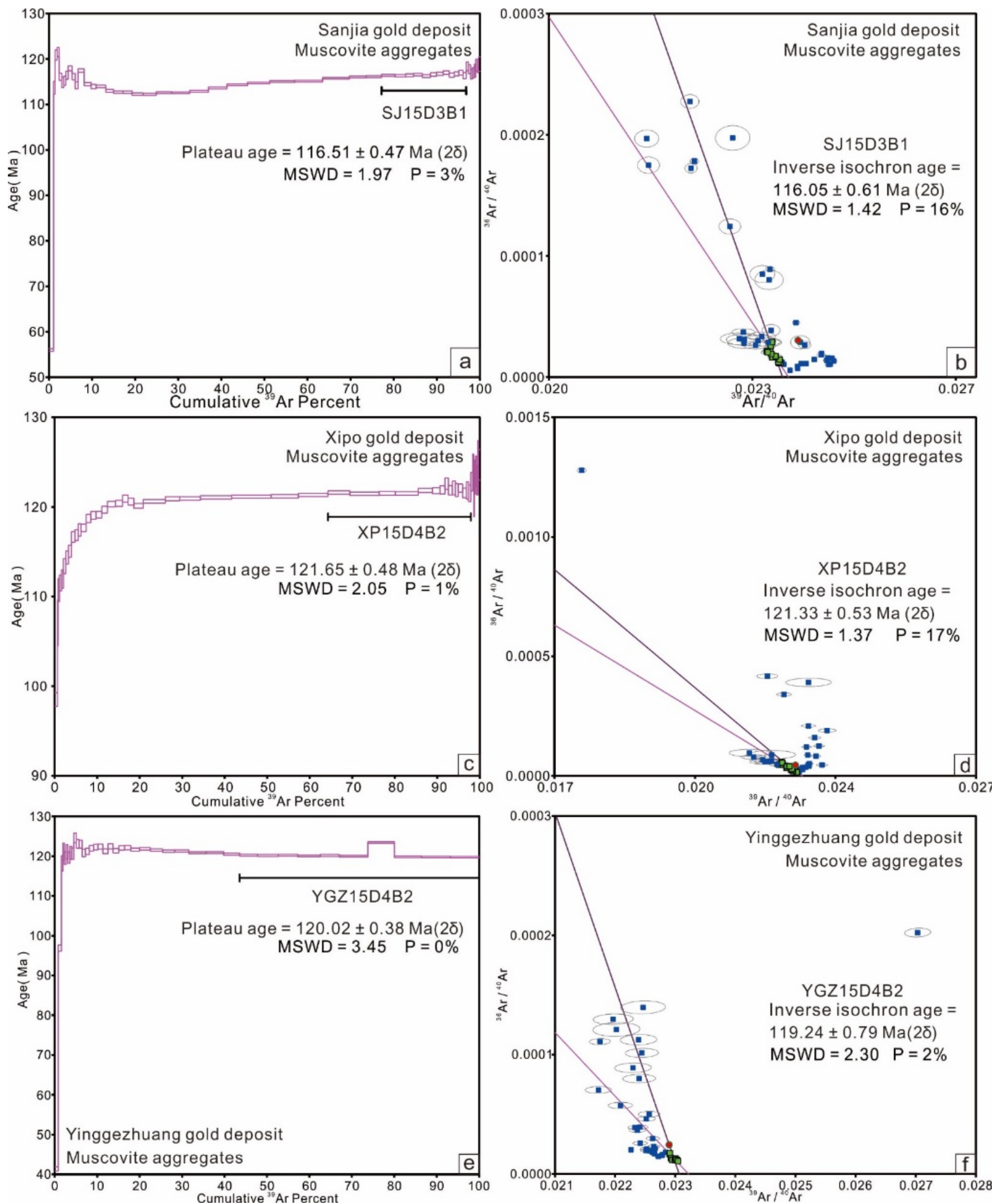

Figure $5 .{ }^{40} \mathrm{Ar} /{ }^{39} \mathrm{Ar}$ plateau ages $(2 \sigma)$ and the inverse isochron ages of the hydrothermal muscovite obtained from the Sanjia, Xipo, and Yinggezhuang gold deposits: (a) plateau age of the Sanjia gold deposit, (b) inverse isochron age of the Sanjia gold deposit, (c) plateau age of the Xipo gold deposit, (d) inverse isochron age of the Xipo gold deposit, (e) plateau age of the Yinggezhuang gold deposit, and (f) inverse isochron age of the Yinggezhuang gold deposit. The black line means the atmospheric argon, and the purple line means the trapped argon in $(\mathbf{b}, \mathbf{d}, \mathbf{f})$. 


\section{Discussion}

\subsection{Regional Metallogenic Time}

Ar-Ar muscovite, SHRIMP zircon, $\mathrm{Rb}-\mathrm{Sr}$ pyrite, and other ages have been reported by previous studies. The test results ranged from $107.7 \pm 0.5 \mathrm{Ma}$ to $128.8 \pm 0.1 \mathrm{Ma}$ as illustrated in Table 2.

Table 2. Mineralization age in the Muping-Rushan gold belt.

\begin{tabular}{|c|c|c|c|c|}
\hline Deposit & Sample & Method & Age (Ma) & Reference \\
\hline \multirow{7}{*}{ Jinqingding } & Muscovite & ${ }^{40} \mathrm{Ar}-{ }^{39} \mathrm{Ar}$ & $107.7 \pm 0.5-109.3 \pm 0.3$ & {$[24]$} \\
\hline & Zircon in the quartz vein & Shrimp U-Pb & $117 \pm 3$ & [25] \\
\hline & Muscovite & ${ }^{40} \mathrm{Ar}-{ }^{39} \mathrm{Ar}$ & $128.8 \pm 0.1$ & {$[15]$} \\
\hline & Beresite & $\mathrm{Rb}-\mathrm{Sr}$ & $104.8 \pm 1.5$ & [27] \\
\hline & K-feldspar & $\mathrm{Rb}-\mathrm{Sr}$ & $121.3 \pm 0.587$ & [26] \\
\hline & Beresite & $\mathrm{Rb}-\mathrm{Sr}$ & $113.3 \pm 4.4$ & [26] \\
\hline & Muscovite & ${ }^{40} \mathrm{Ar}-{ }^{39} \mathrm{Ar}$ & $119.7 \pm 0.2$ & {$[1]$} \\
\hline Hubazhuang & Muscovite & $\mathrm{Rb}-\mathrm{Sr}$ & $126.5 \pm 5.6$ & [20] \\
\hline \multirow{2}{*}{ Denggezhuang } & Fluid inclusion in the quartz & ${ }^{40} \mathrm{Ar}-{ }^{39} \mathrm{Ar}$ & 117.5 & {$[28]$} \\
\hline & Beresite & $\mathrm{Rb}-\mathrm{Sr}$ & $118 \pm 9$ & [29] \\
\hline \multirow{2}{*}{ Yinggezhuang } & K-feldspar & ${ }^{40} \mathrm{Ar}-{ }^{39} \mathrm{Ar}$ & $111.24 \pm 0.71$ & {$[30]$} \\
\hline & Muscovite & ${ }^{40} \mathrm{Ar}-{ }^{39} \mathrm{Ar}$ & $119.24 \pm 0.79$ & This study \\
\hline Sanjia & Muscovite & ${ }^{40} \mathrm{Ar}-{ }^{39} \mathrm{Ar}$ & $116.05 \pm 0.61$ & This study \\
\hline Xipo & Muscovite & ${ }^{40} \mathrm{Ar}-{ }^{39} \mathrm{Ar}$ & $121.65 \pm 0.48$ & This study \\
\hline
\end{tabular}

A wide range of dating results have been obtained from studies on the Jinqingding gold deposit. Li et al. [24] reported 107.7 $\pm 0.5-109.3 \pm 0.3 \mathrm{Ma}$ using ${ }^{40} \mathrm{Ar} /{ }^{39} \mathrm{Ar}$ on muscovite. Hu et al. [25] obtained $117 \pm 3 \mathrm{Ma}$ using SHRIMP U-Pb zircon in quartz veins. Zhang et al. [26] and Zhai and Hu [27] reported 104.8 $\pm 1.5 \mathrm{Ma}$ and 113.3 $\pm 4.4 \mathrm{Ma}$ using $\mathrm{Rb}-\mathrm{Sr}$ on muscovite, respectively. Hu et al. [15] obtained $128.8 \pm 0.1 \mathrm{Ma}$ using ${ }^{40} \mathrm{Ar} /{ }^{39} \mathrm{Ar}$ on muscovite from beresite. Zhang et al. [26] reported $121.3 \pm 0.587 \mathrm{Ma}$ using $\mathrm{Rb}-\mathrm{Sr}$ on $\mathrm{K}$-feldspar. Zhang et al. [1] reported $119.7 \pm 0.2 \mathrm{Ma}$ using ${ }^{40} \mathrm{Ar} /{ }^{39} \mathrm{Ar}$ on muscovite. Cai et al. [20] obtained 126.5 $\pm 5.6 \mathrm{Ma}$ using Rb-Sr on muscovite in the Hubazhuang gold deposit. In the Denggezhuang gold deposit, Zhao and $\mathrm{Wu}$ [28] reported 117.5 Ma using ${ }^{40} \mathrm{Ar} /{ }^{39} \mathrm{Ar}$ on inclusions in quartz; Zhang and $\mathrm{Xu}$ [29] obtained $118 \pm 9 \mathrm{Ma}$ using $\mathrm{Rb}-\mathrm{Sr}$ on muscovite. In the Yinggezhuang gold deposit, Cui [30] obtained 111.24 \pm 0.71 Ma using ${ }^{40} \mathrm{Ar} /{ }^{39} \mathrm{Ar}$ on K-feldspar.

The dating results differ for various reasons. Samples for dating, such as beresite and fluid inclusion, are easily contaminated by later hydrothermal activities, which may cause mixed results. The initial value of the sample for $\mathrm{Rb}-\mathrm{Sr}$ isochron dating was uneven, which produced uncertainty in the result. This evidence indicated that K-feldspar could not be related to mineralization.

Muscovite from the Jinqingding gold deposit (Figure 1) coexists with gold in the fracture of pyrite, which showed a strong relationship between muscovite and mineralization [11]; thus, ${ }^{40} \mathrm{Ar} /{ }^{39} \mathrm{Ar}$ on muscovite appeared reliable in terms of systematics. The hydrothermal muscovite ${ }^{40} \mathrm{Ar} /{ }^{39} \mathrm{Ar}$ age of $128.8 \pm 0.1 \mathrm{Ma}$ was considered as a premineralization alteration age [15]. The ${ }^{40} \mathrm{Ar} /{ }^{39} \mathrm{Ar}$ ages of 109.3 to $107.7 \mathrm{Ma}$ [24] apparently represented a late local thermal reset by intrusion of the Aishan granite dike swarms (minimum age of $108 \mathrm{Ma}$ ). Except for the data from Li et al. [24] and Hu et al. [15], the age of ${ }^{40} \mathrm{Ar} /{ }^{39} \mathrm{Ar}$ on muscovite ranged from $116.05 \mathrm{Ma}$ to $121.65 \mathrm{Ma}$. 
Zhang [60] found three stages of gold mineralization in the northwest of the Jiaodong Peninsula. The early-stage gold mineralization occurred in the Late Jurassic ( 162 Ma), which came from the Pinglidian gold deposit in the Jiaojia fault zone [60]. The middlestage gold mineralization occurred at approximately $130 \pm 4 \mathrm{Ma}$ and mainly came from the Dayingezhuang and Xiadian gold deposits in the Zhaoyuan-Pingdu fault zone [35]. The early and middle stages of gold mineralization were less developed. The main gold mineralization occurred at approximately $120 \mathrm{Ma}$ [1].

The gold deposits selected for this study were located in the Jinniushan and Sanjia faults. Three dating results were in the range of $120 \pm 5 \mathrm{Ma}$. The existing dating data of the Muping-Rushan gold belt were approximately $120 \mathrm{Ma}$.

\subsection{Relationship between Mineralization and Magmatism}

The Yanshan Movement in eastern China lasted from the Middle-Late Jurassic to the Early Cretaceous (170-130 Ma); the tectonic regimes transformed from the Paleo-Asian and Tethyan tectonic domains to the Paleo-Pacific tectonic domain [61-64].

In the Late Jurassic, intraplate syntectonic calc-alkaline granites intruded into Linglong, Kunyushan, Queshan, and Wendeng from west to east [35], as shown in Figure 6. This phenomenon might be related to the intracontinental compression deformation caused by the subduction and convergence of the Paleo-Pacific Plate and the strong sinistral strike slip of the Tancheng-Lujiang fault [65]. Subsequently, the Jiaodong Peninsula has experienced NWW-SEE extension (110-100 Ma), NW-SE compression (100-85 Ma), NNWSSE extension (80-65 Ma), NE-SW compression (65-50 Ma), and NW-SE compression (50 Ma to date) [35].

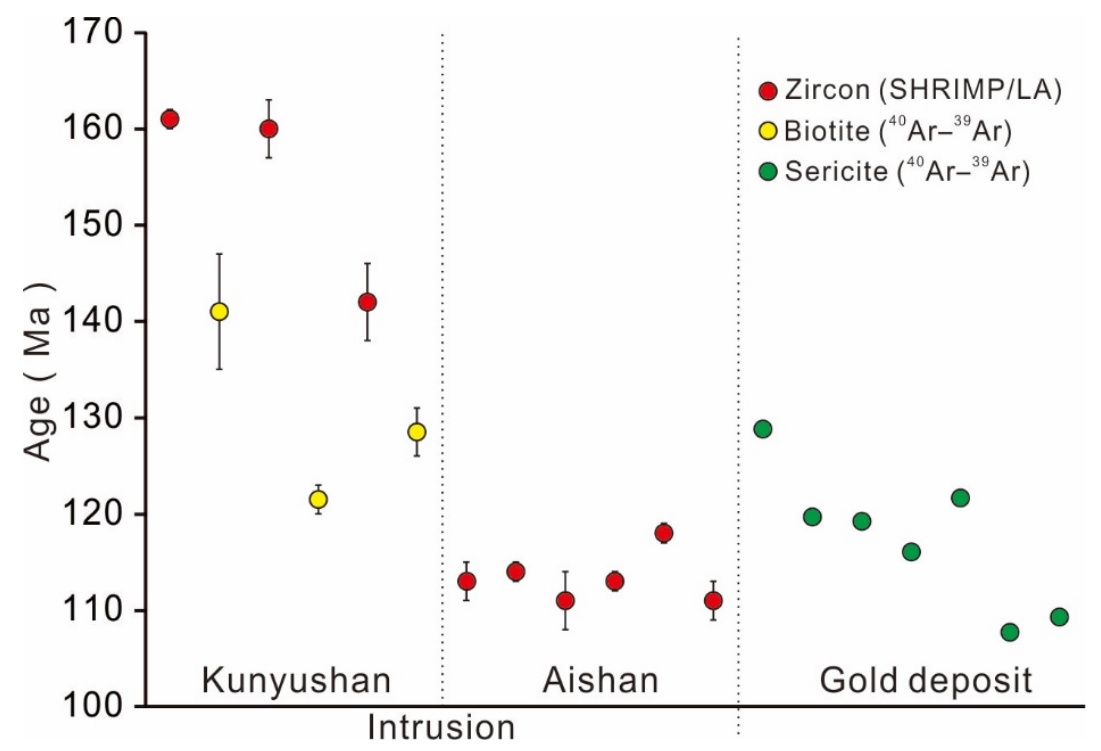

Figure 6. Time limit of gold mineralization in comparison to the magmatism in the Muping-Rushan gold belt (data are from $[1,24,29,50-52])$.

Correspondingly, the Muping-Rushan gold belt has experienced a thermal history of rapid cooling, heat setting after a slight rise in temperature, medium speed cooling and heat setting, and monotonic cooling, which have slowly reduced to the current temperature [66]. The metallogenic depth of the Muping-Rushan gold belt may be slightly less than $7.1-14.2 \mathrm{~km}$, the shallow part $(5.5-7.2 \mathrm{~km})$ has been eroded after mineralization, and the deep part still contains a considerable amount of resource potential [66].

The magmatic-hydrothermal activity was closely related to the intrusion and only lasted for a short time. Although multiple intrusions would cause hydrothermal circulation, the associated pulse can only last for about $1 \mathrm{Ma}$ [67]. The Kunyushan and Aishan granites formed the main wall rock in the Muping-Rushan gold belt; the youngest zircon SHRIMP 
age of the Kunyushan granite was 16 (138-122) Ma earlier than the mineralization age, and only the youngest cooling biotite ${ }^{40} \mathrm{Ar} /{ }^{39} \mathrm{Ar}$ age overlapped the mineralization, whereas the gold deposits were not located in the Washan granite. No Early Cretaceous granite (132-123 Ma) was found in the study area, although the intrusion time overlapped the mineralization age, which could remove the impact of the Early Cretaceous granite. The mean intrusion time of the Aishan granite was approximately $115 \mathrm{Ma}$ [1], and the Sanfoshan granite was several kilometers away from the deposit.

The freezing temperature of the ore fluid ranged from $-0.1{ }^{\circ} \mathrm{C}$ to $-9.8^{\circ} \mathrm{C}$, the homogenization temperatures varied between $170{ }^{\circ} \mathrm{C}$ and $350^{\circ} \mathrm{C}$, the calculated salinity was from $0.2 \mathrm{wt} \%$ to $13.73 \mathrm{wt} \% \mathrm{NaCl}$ eq., and no salt daughter minerals were found [68]. This result is largely inconsistent with that of magmatic-hydrothermal fluid $\left(>500{ }^{\circ} \mathrm{C}\right.$, high salinity [69-72]). Additionally, no metal zonation from proximal $\mathrm{Au}-\mathrm{Bi}-\mathrm{Te}$ to distal $\mathrm{Ag}-\mathrm{Pb}-\mathrm{Zn}$ assemblages was found in the Muping-Rushan gold belt, which is typical of granite-related deposits [73-75]. Therefore, the gold deposits in the Muping-Rushan gold belt could not be classified as an intrusion-related gold system.

\subsection{Orogenic Gold Deposit in the Muping-Rushan Gold Belt}

The integrated mineral system model in Jiaodong has been summarized in previous studies [2,23,76]. The gold mineralization in the Muping-Rushan gold belt was 1.8 1.7 billion years after orogenesis and regional metamorphism in Jiaodong [1,2], which is different from the typical orogenic gold deposit. The gold deposits in the Muping-Rushan belt share similar features with orogenic gold deposits, such as the feature of the ore fluid, structural control, and quartz-pyrite-muscovite-carbonate alteration assemblages [5,6,11].

In the Jurassic, the Pacific Plate subducted below the North China Craton and retreated [24,36-38], and brittle deformation in the ore-controlling faults occurred in the Early Cretaceous [55]. Advances in the orogenic gold deposit model have attempted to explain the gold deposit in Jiaodong [77], and ore fluids are ascribed directly to the devolatilization of either the subducting slab, overlying sediment wedge, or lithosphere $[23,76,77]$. The mineralization in the Muping-Rushan gold belt may be related to the retreat of the Paleo-Pacific Plate, and the mantle wedge could provide the necessary ore fluid [77]. Thus, gold deposits in the Muping-Rushan gold belt should be categorized into the orogenic gold system.

\section{Summary}

(1) Ar-Ar tests were performed on the muscovite from quartz-sulfide veins and beresite from the Sanjia, Yinggezhuang, and Xipo gold deposits. The metallogenic ages of the Sanjia, Yinggezhuang, and Xipo gold deposits were $116.51 \pm 0.47 \mathrm{Ma}$, $120.02 \pm 0.38 \mathrm{Ma}$, and $121.65 \pm 0.48 \mathrm{Ma}$, respectively.

(2) By combining the mineralization and magmatism ages and ore fluid feature, gold deposits in the Muping-Rushan gold belt should be categorized into the orogenic gold system rather than an intrusion-related gold system.

Supplementary Materials: The following are available online at https:/ / www.mdpi.com/article/ 10.3390/min12030278/s1: Table S1: 40Ar/39Ar data of muscovite furnace stage heating in beresite of the Sanjia gold deposit. Table S2: 40Ar/39Ar data of muscovite furnace stage heating in quartzsulfide vein of the Xipo gold deposit. Table S3: 40Ar/39Ar data of muscovite furnace stage heating in quartz-sulfide vein of the Yinggezhuang gold deposit.

Author Contributions: B.C. and J.D. conceived and designed the ideas; B.C. and X.J. analyzed the data; B.C. prepared the original draft; B.C. and X.J. reviewed and edited the draft. All authors have read and agreed to the published version of the manuscript.

Funding: This research was funded by the National Mineral Resources Assessment Project (41372007, DD20190193, DD20190606), the National Natural Science Foundation of China (Grant No. 41572069), funds from the State Key Laboratory of Geological Processes and Mineral Resources, the China University of Geosciences (Grant No. MSFGPMR201804), and Project 111 under the Ministry of 
Education and the State Administration of Foreign Experts Affairs, China (Grant No. B07011), and the China Scholarship Council (No. 201506400013).

Data Availability Statement: Not applicable.

Acknowledgments: Many thanks to Zhongliang Wang, Yue Liu, Shengxun Sai, and Sirui Wang from the China University of Geosciences (Beijing) for help during fieldwork. Many thanks to the geologists for their assistance in fieldwork at the Sanjia, Xipo, and Yinggezhuang gold deposits. Many thanks to Daniel P. Miggins for the Ar-Ar dating. The authors would like to thank all the reviewers who participated in the review.

Conflicts of Interest: The authors declare no conflict of interest.

\section{References}

1. Zhang, L.; Weinberg, R.F.; Yang, L.Q.; Groves, D.I.; Sai, S.X.; Matchan, E.; Phillips, D.; Kohn, B.P.; Miggins, D.P.; Liu, Y.; et al. Mesozoic orogenic gold mineralization in the Jiaodong peninsula, China: A focused event at $120 \pm 2$ Ma during cooling of pregold granite intrusions. Econ. Geol. 2020, 115, 415-441. [CrossRef]

2. Qiu, K.F.; Goldfarb, R.J.; Deng, J.; Yu, H.C.; Gou, Z.Y.; Ding, Z.J.; Wang, Z.K.; Li, D.P. Gold deposits of the Jiaodong Peninsula, eastern China. SEG Spec. Publ. 2020, 23, 753-773. [CrossRef]

3. Goldfarb, R.J.; Mao, J.W.; Qiu, K.F.; Goryachev, N. The great Yanshanian metallogenic event of eastern Asia: Consequences from one hundred million years of plate margin geodynamics. Gondwana Res. 2021, 100, 223-250. [CrossRef]

4. Zhai, Y.S.; Yao, S.Z.; Cai, K.Q. Ore Deposit Geology; Geological Publishing House: Beijing, China, 2011. (In Chinese)

5. Goldfarb, R.J.; Santosh, M. The dilemma of the Jiaodong gold deposits: Are they unique? Geosci. Front. 2014, 5, 139-153. [CrossRef]

6. Groves, D.I.; Santosh, M. The giant Jiaodong gold province: The key to a unified model for orogenic gold deposits? Geosci. Front. 2016, 7, 409-417. [CrossRef]

7. Zhai, M.G.; Fan, H.R.; Yang, J.H.; Miao, L.C. Large-scale cluster of gold deposits in east Shandong: Anorogenic metallogenesis. Earth Sci. Front. 2004, 11, 85-98. (In Chinese with English Abstract)

8. Zhu, R.X.; Fan, H.R.; Li, J.W.; Meng, Q.R.; Li, S.R.; Zeng, Q.D. Decratonic gold deposits. Sci. China Earth Sci. 2015, 58, 1523-1537. [CrossRef]

9. Li, L.; Santosh, M.; Li, S.R. The "Jiaodong type" gold deposits: Characteristics, origin and prospecting. Ore Geol. Rev. 2015, 65, 589-611. [CrossRef]

10. Deng, J.; Wang, Q.F. Gold mineralization in China: Metallogenicprovinces, deposit types and tectonic framework. Gondwana Res. 2016, 36, 219-274. [CrossRef]

11. Chen, B.; Deng, J.; Wei, H.; Ji, X. Trace element geochemistry in quartz in the Jinqingding gold deposit, Jiaodong peninsula, China: Implications for the gold precipitation mechanism. Minerals 2019, 9, 326. [CrossRef]

12. Chen, H.Y. Genetic Mineralogy and Deep Prospects of Jinqingding Gold Deposit in Rushan, East Shandong Province. Master's Thesis, China University of Geosciences, Beijing, China, 2012. (In Chinese with English Abstract)

13. Hou, X.H.; Luo, T.M.; Wang, T.J.; Zhang, H.S.; Zang, K.H. Characteristics of geology and geochemistry of the Yinggezhuang gold deposit in Eastern Shandong Province. Geol. Explor. 2010, 46, 910-920.

14. Mao, J.W.; Li, H.M.; Wang, Y.T.; Zhang, C.Q.; Wang, R.T. The relationship between mantle-derived fluid and gold ore-formation in the Eastern Shandong peninsula: Evidences from D-O-C-S isotopes. Acta. Geol. Sin. 2005, 6, 839-857. (In Chinese with English abstract)

15. Hu, F.F.; Fan, H.R.; Zhai, M.G.; Jin, C.W. Fluid evolution in the Rushan lode gold deposit of Jiaodong peninsula, eastern China. J. Geochem. Explor. 2006, 89, 161-164. [CrossRef]

16. Hu, F.F.; Fan, H.R.; Yang, K.F.; Shen, K.; Zhai, M.G.; Jin, C.W. Fluid inclusions in the Denggezhuang lode gold deposit at Muping, Jiaodong peninsula. Acta Petrol. Sin. 2007, 23, 2155-2164. (In Chinese with English Abstract)

17. Hu, F.F.; Fan, H.R.; Yu, H.; Liu, Z.H.; Song, L.F.; Jin, C.W. Fluid inclusions in the Sanjia lode gold deposit, Jiaodong peninsula of eastern China. Acta Petrol. Sin. 2008, 24, 2037-2044. (In Chinese with English Abstract)

18. Shen, P.; Shen, Y.; Li, G.; Liu, T.; Zeng, Q.; Li, H. A study on structure-fluid-mineralization system in the Jinniushan gold deposit, East Shandong. Chin. J. Geol. 2004, 39, 272-283. (In Chinese with English Abstract)

19. Zhou, Q.F. Genetic mineralogy and Deep Prospects of the Yinggezhuang Gold Deposit in Rushan County, Jiaodong. Master's Thesis, China University of Geosciences, Beijing, China, 2010. (In Chinese with English Abstract)

20. Cai, Y.C.; Fan, H.R.; Yang, K.F.; Hu, F.F.; Yu, H.; Liu, Y.M.; Lan, T.G. Ore-forming fluids, stable isotope and mineralizing age of the Hubazhuang gold deposit, Jiaodong peninsula of eastern China. Acta Petrol. Sin. 2011, 27, 1341-1351.

21. Lan, T.G.; Fan, H.R.; Hu, F.F.; Yang, K.F.; Liu, X.; Liu, Z.H.; Song, Y.B.; Yu, H. Characteristics of ore-forming fluids and ore genesis in the Shicheng gold deposit, Jiaodong peninsula of eastern China. Acta Petrol. Sin. 2010, 26, 1512-1522. (In Chinese with English Abstract)

22. Zeng, Q.; Liu, J.; Liu, H.; Shen, P.; Zhang, L. The ore-forming fluid of the gold deposits of Muru gold belt in Eastern Shandong, China-A case study of Denggezhuang gold deposit. Resour. Geol. 2006, 56, 375-384. [CrossRef] 
23. Deng, J.; Qiu, K.F.; Wang, Q.F.; Goldfarb, R.J.; Yang, L.Q.; Zi, J.W.; Geng, J.Z.; Ma, Y. In-situ dating of hydrothermal monazite and implications on the geodynamic controls of ore formation in the Jiaodong gold province, Eastern China. Econ. Geol. 2020, 115, 671-685. [CrossRef]

24. Li, J.W.; Vasconcelos, P.; Zhou, M.F.; Zhao, X.F.; Ma, C.Q. Geochronology of the Pengjiakuang and Rushan gold deposits, eastern Jiaodong gold province, northeastern China: Implications for regional mineralization and geodynamic setting. Econ. Geol. 2006, 101, 1023-1038. [CrossRef]

25. Hu, F.F.; Fan, H.R.; Yang, J.H.; Wan, Y.S.; Liu, D.Y.; Zhai, M.G.; Jin, C.W. Mineralizing age of the Rushan lode gold deposit in the Jiaodong peninsula: SHRIMP U-Pb dating on hydrothermal zircon. Chinese Sci. Bull. 2004, 49, 1629-1636. [CrossRef]

26. Zhang, Z.H.; Zhang, J.X.; Ye, S.Z. Determination of Isotopic age of Jiaodong Gold Deposit; Seismological Press: Beijing, China, 1994; pp. 1-56. (In Chinese)

27. Zhai, J.P.; Hu, K.; Lu, J.J. Lamprophyres ore forming fluids and H, O, Sr isotope studies of the Rushan gold deposit. Miner. Depos. 1996, 4, 358-365. (In Chinese with English Abstract)

28. Zhao, L.S.; Wu, Y.B.; Ye, R.; Lu, H. Study on tectonic-geochemical dynamics of ore-formation in Jiaodong auriferous area. Geosci. J. Grad. Sch. China Univ. Geosci. 1996, 10, 213-221. (In Chinese with English Abstract)

29. Zhang, D.Q.; Xu, H.L.; Sun, G.Y. Emplacement ages of the Denggezhuang gold deposit and the Kunyushan granite and their geological implications. Geol. Rev. 1995, 41, 415-425. (In Chinese)

30. Cui, J.C. Genetic Mineralogy in Gold Ore-Forming Belt of Muping-Rushan in Jiaodong. Master's Thesis, China University of Geosciences, Beijing, China, 2012. (In Chinese with English Abstract)

31. Qiu, K.F.; Yu, H.C.; Wu, M.Q.; Geng, J.Z.; Ge, X.K.; Gou, Z.Y.; Taylor, R.D. Discrete Zr and REE mineralization of the Baerzhe rare-metal deposit, China. Am. Mineral. 2019, 104, 1487-1502. [CrossRef]

32. Yang, L.Q.; Deng, J.; Dilek, Y.; Qiu, K.F.; Ji, X.Z.; Li, N.; Taylor, R.D.; Yu, J.Y. Structure, geochronology, and petrogenesis of the Late Triassic Puziba granitoid dikes in the Mianlue suture zone, Qinling Orogen, China. Geol. Soc. Am. Bull. 2015, 11/12, 1831-1854. [CrossRef]

33. Deng, J.; Yang, L.-Q.; Li, R.-H.; Groves, D.I.; Santosh, M.; Wang, Z.-L.; Sai, S.-X.; Wang, S.-R. Regional structural control on the distribution of world-class gold deposits: An overview from the giant Jiaodong gold province. China. Geol. J. 2018, 54, 378-391. [CrossRef]

34. Yang, L.Q.; Deng, J.; Wang, Z.L.; Zhang, L.; Goldfarb, R.J.; Yuan, W.M.; Weinberg, R.F.; Zhang, R.-Z. Thermochronologic constraints on evolution of the Linglong metamorphic core complex and implications for gold mineralization: A case study from the Xiadian gold deposit, Jiaodong peninsula, eastern China. Ore Geol. Rev. 2016, 72, 165-178. [CrossRef]

35. Yang, L.Q.; Deng, J.; Goldfarb, R.J.; Zhang, J.; Gao, B.F.; Wang, Z.L. ${ }^{40} \mathrm{Ar} /{ }^{39} \mathrm{Ar}$ geochronological constraints on the formation of the Dayingezhuang gold deposit: New implications for timing and duration of hydrothermal activity in the Jiaodong gold province, China. Gondwana Res. 2014, 25, 1469-1483. [CrossRef]

36. Wang, Z.L. Metallogenic System of Jiaojia Gold Ore Field, Shandong Province, China. Ph.D. Thesis, China University of Geosciences, Beijing, China, 2012. (In Chinese with English Abstract)

37. Tan, J.; Wei, J.; Li, Y.; Tan, W.; Guo, D.; Yang, C. Geochemical characteristics of late Mesozoic dikes, Jiaodong peninsula, North China Craton: Petrogenesis and geodynamic setting. Int. Geo. Rev. 2007, 49, 931-946. [CrossRef]

38. Qiu, Y.; Groves, D.I.; McNaughton, N.J.; Wang, L.-G.; Zhou, T. Nature, age, and tectonic setting of granitoid-hosted, orogenic gold deposits of the Jiaodong peninsula, eastern North China craton, China. Miner. Depos. 2002, 37, 283-305. [CrossRef]

39. Jahn, B.M.; Liu, D.; Wan, Y.; Song, B.; Wu, J. Archean crustal evolution of the Jiaodong peninsula, China, as revealed by zircon shrimp geochronology elemental and Nd-isotope geochemistry. Am. J. Sci. 2008, 308, 232-269. [CrossRef]

40. Deng, J.; Wang, Q.; Wan, L.; Liu, H.; Yang, L.; Zhang, J. A multifractal analysis of mineralization characteristics of the Dayingezhuang disseminated-veinlet gold deposit in the Jiaodong gold province of China. Ore Geol. Rev. 2011, 40, 54-64. [CrossRef]

41. Wan, Y.S.; Dong, C.Y.; Xie, H.Q.; Wang, S.J.; Song, M.C.; Xu, Z.Y.; Wang, S.Y.; Zhou, H.Y.; Ma, M.Z.; Liu, D.Y. Formation ages of early Precambrian BIFs in the North China craton: SHRIMP zircon U-Pb dating. Acta Geol. Sin. 2012, 86, 1447-1478. (In Chinese)

42. Dong, C.Y.; Wang, S.J.; Liu, D.Y.; Wang, J.G.; Xie, H.Q.; Wang, W.; Song, Z.Y.; Wan, Y.S. Late Paleoproterozoic crustal evolution of the North China craton and formation time of the Jingshan group: Constraints from SHRIMP U-Pb zircon dating of metaintermediate-basic intrusive rocks in eastern Shandong province. Acta Petrol. Sin. 2010, 27, 1699-1706. (In Chinese with English Abstract)

43. Li, X.P.; Liu, Y.J.; Guo, J.H.; Li, H.K.; Zhao, G. Petrogeochemical characteristics of the Paleoproterozoic high-pressure mafic granulite and calc-silicate from the Nanshankou of the Jiaobei terrane. Acta Petrol. Sin. 2013, 29, 2340-2352. (In Chinese with English Abstract)

44. Liu, P.H.; Liu, F.L.; Wang, F.; Liu, J.H.; Cai, J. Petrological and geochronological preliminary study of the Xiliu 2.1Ga meta-gabbro from the Jiaobei terrane, the southern segment of the Jiao-Liao-Ji Belt in the North China Craton. Acta Petrol. Sin. 2013, 29, 2371-2390. (In Chinese with English Abstract)

45. Faure, M.; Lin, W.; Monie, P.; Bruguier, O. Paleoproterozoic arc magmatism and collision in Liaodong peninsula (north-east China). Terra Nova 2004, 16, 75-80. [CrossRef]

46. Hu, S.; Wang, S.; Sang, H.; Qiu, J.; Zhang, R. Isotopic ages of Linglong and Guojialing batholiths in Shandong province and their geological implication. Acta Petrol. Sin. 1987, 3, 83-89. (In Chinese with English Abstract) 
47. Guan, K.; Luo, Z.K.; Miao, L.C.; Huang, J.Z. SHRIMP in zircon chronology for Guojialing suite granite in Jiaodong Zhaoye district. Sci. Geol. Sin. 1998, 33, 318-328. (In Chinese with English Abstract)

48. Jiang, N.; Chen, J.; Guo, J.; Chang, G. In situ zircon U-Pb, oxygen and hafnium isotopic compositions of Jurassic granites from the North China craton: Evidence for Triassic subduction of continental crust and subsequent metamorphism-related ${ }^{18} \mathrm{O}$ depletion. Lithos 2012, 142, 84-94. [CrossRef]

49. Yang, K.-F.; Fan, H.-R.; Santosh, M.; Hu, F.-F.; Wilde, S.A.; Lan, T.-G.; Lu, L.-N.; Liu, Y.S. Reactivation of the Archean lower crust: Implications for zircon geochronology, elemental and Sr-Nd-Hf isotopic geochemistry of late Mesozoic granitoids from northwestern Jiaodong Terrane, the North China craton. Lithos 2012, 146, 112-127. [CrossRef]

50. Guo, J.H.; Chen, F.K.; Zhang, X.M.; Siebel, W.; Zhai, M.G. Evolution of syn-to post-collisional magmatism from north Sulu UHP belt, eastern China: Zircon U-Pb geochronology. Acta Petrol. Sin. 2005, 21, 1281-1301. (In Chinese with English Abstract)

51. Hu, F.F. Magmatism, Ore Fluid Evolution and Gold Mineralization of the Kunyushan Area in the Jiaodong Peninsula during the Mesozoic Tectonic Regime Inversion in Eastern China. Ph.D. Thesis, Chinese Academy of Sciences, Beijing, China, 2006. (In Chinese with English Abstract)

52. Goss, S.C.; Wilde, S.A.; Wu, F.; Yang, J. The age, isotopic signature and significance of the youngest Mesozoic granitoids in the Jiaodong terrane, Shandong province, North China craton. Lithos 2010, 3, 309-326. [CrossRef]

53. Liang, Y.Y. Petrogenesis of the Early Cretaceous Mafic Dikes and Metallogenic Dynamics in Jiaodong Peninsula. Ph.D. Thesis, China University of Geosciences, Beijing, China, 2017. (In Chinese with English Abstract)

54. Zhu, D.C.; Xu, Q.L.; Lü, D.W.; Yang, S.P.; Yang, Z.Y.; Yang, Q.; Shen, X.L. The relationship between lamprophyre and gold mineralization in the Denggezhuang gold deposit along the Northern Section of the Mouping-Rushan metallogenic belt, Shandong Province. Acta Geoscientica Sin. 2018, 39, 319-328. (In Chinese with English Abstract)

55. Cheng, N.N.; Shi, M.Y.; Hou, Q.L.; Pan, J.N.; He, M.; Yan, F.C. Ar-Ar chronology of the brittle deformation age for theorecontrolling shear zones in the Jiaodong Peninsula and its constrains on gold mineralization. Acta Petrol. Sin. 2021, 37, 3656-3672. (In Chinese with English Abstract). [CrossRef]

56. Kuiper, K.F.; Deino, A.; Hilgen, F.J.; Krijgsman, W.; Renne, P.R.; Wijbrans, J.R. Synchronizing rock clocks of Earth history. Science 2008, 320, 500-504. [CrossRef]

57. Phillips, D.; Matchan, E.L. Ultra-high precision ${ }^{40} \mathrm{Ar} /{ }^{39} \mathrm{Ar}$ ages for Fish canyon Tuff and Alder creek Rhyolite sanidine: New dating standards required? Geochim. Cosmochim. Acta 2013, 121, 229-239. [CrossRef]

58. Matchan, E.L.; Phillips, D. High precision multi-collector ${ }^{40} \mathrm{Ar} /{ }^{39} \mathrm{Ar}$ dating of young basalts: Mount Rouse volcano (SE Australia) revisited. Quat. Geochronol. 2014, 22, 57-64. [CrossRef]

59. Min, K.; Mundil, R.; Renne, P.R.; Ludwig, K.R. A test for systematic errors in ${ }^{40} \mathrm{Ar} /{ }^{39} \mathrm{Ar}$ geochronology through comparison with $\mathrm{U} / \mathrm{Pb}$ analysis of a 1.1-Ga rhyolite. Geochim. Cosmochim. Acta 2000, 64, 73-98. [CrossRef]

60. Zhang, L. Application of Thermochronology to Hydrothermal Gold Deposits, Northwestern Jiaodong Peninsula, China. Ph.D. Thesis, China University of Geosciences, Beijing, China, 2016. (In Chinese with English Abstract)

61. Wu, F.Y.; Xu, Y.G.; Gao, S.; Zheng, J.P. Lithospheric thinning and destruction of the North China craton. Acta Petrol. Sin. 2008, 24, 1145-1174. (In Chinese with English Abstract)

62. Zhao, Y.; Xu, G.; Zhang, S.H.; Yang, Z.Y.; Zhang, Y.Q.; Hu, J.M. Yanshanian movement and conversion oftectonic regimes in east Asia. Earth Sci. Front. 2004, 11, 319-328. (In Chinese with English Abstract)

63. Zhai, M.G.; Meng, Q.R.; Liu, J.M.; Hou, Q.L.; Hu, S.B.; Li, Z.; Zhang, H.F.; Liu, W.; Shao, J.; Zhu, R.X. Geological features of Mesozoic tectonic regime inversionin eastern North China and implication for geodynamics. Earth Sci. Front. 2004, 11, $285-297$. (In Chinese with English Abstract)

64. Zhou, X.H. Major transformation of subcontinental lithosphere beneath eastern China in the Cenozoic-Mesozoic: Review and prospect. Earth Sci. Front. 2006, 13, 50-64. (In Chinese with English Abstract)

65. Qiu, L.G.; Ren, F.L.; Cao, Z.X.; Zhang, Y.Q. Late Mesozoic magmatic activities and their constraints on geotectonics of Jiaodong region. Geotecton. Metallog. 2008, 1, 117-124. (In Chinese with English Abstract)

66. Sai, S.X. Structure-Fluid-Metallogeny and Dynamics in the Muru Gold Belt, Jiaodong Peninsula. Ph.D. Thesis, China University of Geosciences, Beijing, China, 2020. (In Chinese with English Abstract)

67. Cathles, L.M.; Erendi, A.H.J.; Barrie, T. How long can a hydrothermal system be sustained by a single intrusive event? Econ. Geol. 1997, 92, 766-771. [CrossRef]

68. Li, Y.P. The genesis of the Rushan gold deposits in east Shandong. Miner. Depos. 1992, 11, 165-172. (In Chinese)

69. Qiu, K.F.; Yu, H.C.; Hetherington, C.; Huang, Y.Q.; Yang, T.; Deng, J. Tourmaline composition and boron isotope signature as a tracer of magmatic-hydrothermal processes. Am. Mineral. 2021, 106, 1033-1044. [CrossRef]

70. Qiu, K.F.; Taylor, R.D.; Song, Y.H.; Yu, H.C.; Song, K.R.; Li, N. Geologic and geochemical insights into the formation of the Taiyangshan porphyry copper-molybdenum deposit, Western Qinling Orogenic Belt, China. Gondwana Res. 2016, 35, 40-58. [CrossRef]

71. Qiu, K.F.; Deng, J.; Yu, H.C.; Wu, M.Q.; Wang, Y.; Zhang, L.; Goldfarb, R. Identifying hydrothermal quartz vein generations in the Taiyangshan porphyry Cu-Mo deposit (West Qinling, China) using cathodoluminescence, trace element geochemistry, and fluid inclusions. Ore Geol. Rev. 2021, 128, 103882. [CrossRef] 
72. Yu, H.C.; Qiu, K.F.; Hetherington, C.J.; Chew, D.; Huang, Y.Q.; He, D.Y.; Geng, J.Z.; Xian, H.Y. Apatite as an alternative petrochronometer to trace the evolution of magmatic systems containing metamict zircon. Contrib. Mineral. Petr. 2021, 176, 68. [CrossRef]

73. Sillitoe, R.H.; Thompson, J.F. Intrusion-related vein gold deposits: Types, tectono-magmatic settings and difficulties of distinction from orogenic gold deposits. Resour. Geol. 1998, 48, 237-250. [CrossRef]

74. Lang, J.R.; Baker, T.; Hart, C.J.R.; Mortensen, J.K. An exploration model for intrusion-related gold systems. SEG Newsl. 2000, 40, 6-15. [CrossRef]

75. Qiu, K.F.; Yu, H.C.; Deng, J.; McIntire, D.; Gou, Z.Y.; Geng, J.Z.; Chang, Z.S.; Zhu, R.; Li, K.N.; Goldfarb, R.J. The giant Zaozigou Au-Sb deposit in west Qinling, China: Magmatic-or metamorphic-hydrothermal origin? Miner. Depos. 2020, 55, 345-362. [CrossRef]

76. Deng, J.; Yang, L.Q.; Groves, D.I.; Zhang, L.; Qiu, K.F.; Wang, Q.F. An integrated mineral system model for the gold deposits of the giant Jiaodong province, eastern China. Earth Sci. Rev. 2020, 208, 103274. [CrossRef]

77. Groves, D.I.; Santosh, M.; Deng, J.; Wang, Q.F.; Yang, L.Q.; Zhang, L. A holistic model for the origin of orogenic gold deposits and its implications for exploration. Miner. Depos. 2020, 55, 275-292. [CrossRef] 